\title{
Auditing Cases That Made A Difference: Mckesson \& Robbins
}

\author{
Sheila D. Foster, Ph.D., CPA, CFE, The Citadel, USA \\ Bruce A. Strauch, J.D., The Citadel, USA
}

\begin{abstract}
Many cases have impacted how today's independent auditor does the job of expressing an opinion on financial statements. Students taking auditing classes memorize the names and dates of the some of these cases, but rarely learn the facts of the cases or appreciate why the cases were so critical to advancing modern auditing standards. McKesson \& Robbins is one of the earliest of these cases. Spanning more than a decade, two continents, two generations and at least four surnames, this case clearly shows students that fraud is not limited to today's corporations and that there is, indeed, little that is new under the sun.
\end{abstract}

Keywords: McKesson \& Robbins, Musica, Auditing, Fraud, Receivables Fraud, Inventory Fraud

\section{INTRODUCTION}

Bootlegger, businessman, smuggler, spy - Guess, oh, guess just who am I?

Bootlegger, businessman, smuggler, spy-Musica, Johnson, Costa, Coster, who am I?

"Beyond any doubt the S.E.C. case which had the greatest impact on the public accounting profession was that involving McKesson \& Robbins, Incorporated."

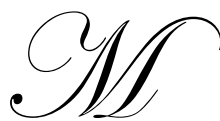

any cases have impacted how today's independent auditor does the job of expressing an opinion on financial statements. Students taking auditing classes memorize the names and dates of the some of these cases, but rarely learn the facts of the cases or appreciate why the cases were so critical to advancing modern auditing standards. McKesson \& Robbins is one of the earliest of these cases. Spanning more than a decade, two continents, two generations and at least four surnames, this case clearly shows students that fraud is not limited to today's corporations and that there is, indeed, little that is new under the sun.

Prior to 1939, auditors generally did not observe the counting of inventory. Instead auditors supported inventory value through written representation. By arguing that they were not qualified to identify and measure inventory, auditors were able to avoid responsibility for quantities and existence of inventory. In the McKesson \& Robbins Co. fraud of 1939, auditors, following generally accepted auditing standards of the day, failed to catch approximately $\$ 10$ million of fictitious inventories and receivables that were overstated by more than $\$ 8$ million. As a direct result of this fraud, two audit procedures - observing inventory and confirming receivables - were added to what were considered acceptable auditing procedures for the day under the guidelines of American Institute of Accountants' 1936 bulletin, Examination of Financial Statements by Independent Public Accountants. [Note that the term "auditor" was not used at this time.]

SAS No. 1 (AU 331), Receivables and Inventories, states that “...it is ordinarily necessary for the independent auditor to be present at the time of count and, by suitable observation, tests, and inquiries, satisfy himself respecting the effectiveness of the methods of inventory-taking and the measure of reliance which may be placed upon the client's representations about the quantities and physical condition of the inventories."

\footnotetext{
${ }^{1}$ Rappaport, p. 41.
} 
Today, if inventories are material and observation is practical, the auditor must observe the counting of inventory. If this audit step is not taken, the auditor bears the burden of justifying the audit opinion. SAS No. 1 does not make the auditor responsible for actually counting inventory; the client is the party responsible for supervising and counting the inventory. The auditor, however, must satisfy himself that inventory is correct.

SAS No. 1 (AU 331) also requires the confirmation of receivables. SAS 67(AU 330), The Confirmation Process, provides additional guidance on the confirmation process and states, in part, that "confirmation of accounts receivable is a generally accepted auditing procedure." Confirmation of accounts receivable is required, except in one of the following three situations:

1. When accounts receivable are not material to financial statements,

2. When confirmations would not be effective (i.e., the auditor expects an inadequate response rate to make confirmation meaningful), or

3. When confirmations are not necessary to reduce audit risk to an acceptably low level for the audit assertions. The auditor may deem that the inherent and control risk are sufficiently low that evidence from other substantive tests and results of analytical procedures provide sufficient audit evidence to allow the auditor to form an opinion on accounts receivable

One case from the 1930s plays a paramount role in causing these two procedures to become part of generally accepted auditing standards. The man behind the case leading to these additional requirements for the auditing process was in immigrant, smuggler, spy, convicted felon, bootlegger, prominent businessman, recipient of a presidential pardon, and almost a candidate for President of the United States.

\section{THE EARLY YEARS - PHILIP MUSICA - THE ITALIAN CHEESE FRAUD}

Philip Musica was born in the squalid neighborhood of Mulberry Bend in New York's lower east side on May 12, 1884, to Antonio and Assunta Mauro Musica. Papa Antonio had been a barber in Italy when Mama Assunta learned that she was pregnant. Determined that her child would not be born into the poverty of Italy, the Musicas immigrated to America. At first, Mr. Musica was content to barber in New York, but Mrs. Musica, who seemed to be the driving force of the family, pushed until her husband opened a small grocery selling cheeses and other imported food items desired by other Italian immigrants of the neighborhood.

Young Philip held himself aloof from the gangs of youth that roved the Mulberry Bend. At age 14, he dropped out of school and joined his father in the grocery business. He quickly learned the import-export business, and A. Musica \& Son soon became such a successful Italian grocery that Philip was able to put a down payment on a mansion Brooklyn, move his family from the squalor of the Lower East Side, become a star of New York society, and begin thinking of himself as "a Diamond Jim Brady with taste."

Unfortunately, not all of the family's fortune had come about legitimately. In 1909, during a political campaign in which charges of "corruption" were hurled against the incumbent, an investigation was begun that uncovered bribery of customs officials by the family. The Musicas had been paying bribes to have their incoming fine Italian cheeses recorded at a fraction of their actual weights allowing the family to avoid tariffs and to make profits far above those of their competitors. On October 29, 1909, Philip and Papa Antonio were indicted for fraud. Like a good son, Philip took full responsibility for the fraud in exchange for a dismissal of the charges against his father. Philip was fined $\$ 5,000$ and sentenced to a year in a reformatory. ${ }^{3}$

In the reformatory, Philip held himself apart from the regular prison population and, although the details of how it was accomplished are scant, Philip walked out of prison five and one-half months after he went in with his sentence commuted by none other than William Howard Taft, President of the United States.

\footnotetext{
${ }^{2}$ Keats, pg. 14

${ }^{3}$ Flaa, p. 6.
} 


\section{THE HAIR FRAUD}

The Musicas returned to the grocery business but avoided the "smelly" cheese business that had given rise to the recent troubles. Without the lucrative cheese business and probably with prodding from Mama Assunta, the family looked for other ways to increase the family fortune. With Papa Antonio's earlier work in barbering, it might not be surprising the Musicas turned to human hair. The high, fancy women's hair fashions of the time required human hair add-ons - all made from imported hair. After all, why sell pasta at 16 cents a pound at A. Musica \& Son Grocery when human hair brought $\$ 80$ a pound? ${ }^{4}$

After the formation of the United States Hair Company, the family wealth began to grow again. The family moved to a larger house, while Philip obtained a suite in midtown Manhattan for his personal use. But this still was not enough for young Philip.

Mama Assunta returned to Naples with letters of introduction and set about courting Italian bankers from whom she obtained large loans using her invoices for human hair as collateral. This would have been fine, except that the crates of hair covered by the invoices contained barbershop sweepings rather than the long lengths of human hair needed for the fashions of the day. Philip, in the meantime, set up offices around the world to deal in human hair and borrowed money in the U.S. against non-existent inventories of human hair. ${ }^{5}$ Like, the crates of human hair collateralizing the loans in Naples, these offices were mere facades, mail drops creating paper transactions for fictitious transactions. Within four months, the United States Hair Company was begun with $\$ 2,000,000$ in assets, including $\$ 600,000$ in non-existent human hair. The company, and the fictitious hair inventory, continued to grow worldwide through phony transactions.

Philip "had discovered a principle that was to be promulgated a quarter-century later by a writer named Adolf Schickelgruber (who used the pen name of A. Hitler): The big lie goes marching on where the tiny fib falls flat on its face... a timorously presented rubber check for $\$ 10$ will arouse the bank president, the board of directors, the American Bankers Association, and the United States Treasury, whereas a bold request for a half-million dollars in credit will evoke only a quick and smiling assent."

On March 11, 1913, five months after the company was first listed on Wall Street, the plot began to unravel. Philip at first tried to use his own funds to prop up the business. However, when he realized that things were impossible, he took invoices for $\$ 370,000$ worth of human hair to a bank and asked for a loan to cover the entire amount. The bank gave him only $\$ 25,000$. He then took duplicates of the invoices to several other banks and received additional loans from many. He also stopped by several jewelry stores to pick up a fortune in diamonds "on approval." With money and jewels in hand, Philip and the family prepared to flee. One alert bank noted that the invoices supporting the loans had been tampered with and an investigation of the crates of hair revealed the sweepings. Instead of $\$ 370,000$, the inventory was worth only $\$ 250$. Even when confronted by the bankers, Philip was able to buy some time by blaming unscrupulous foreign suppliers and promising to clear the matter up in a few days.

Four days later, on March $15^{\text {th }}$, Philip and the family fled. The banks waited two more days before acting enabling the Musicas to stay one step ahead of the law as they fled from New York to New Orleans where they were already aboard a ship bound for Honduras when the police finally caught up with them. Back in New York, auditors tried to trace the lost assets, but the tangled web of finances Philip had woven hid many of them. It was suspected that diamonds on loan from New York jewelers had been sent to Mama Assunta in Naples, but she vigorously denied this allegation. However, she did remain in Naples with three of Philip's younger brothers and sisters until everything settled down in New York.

\footnotetext{
${ }^{4}$ Keats, pp. $17-19$

${ }^{5}$ Flaa, p. 6.

${ }^{6}$ Keats, pg. 22.
} 
Once again, Philip accepted full responsibility for the fraud and asked for clemency for the rest of the family. Now 28 years of age, he blamed corrupt foreign firms for the problems and said the family was fleeing only to gain time to repay all the creditors. Charges against Philip's father and two brothers were dropped; Papa Antonia suffered a heart attack and died shortly afterward; Philip went to the Tombs.

The Tombs was not exactly prison. Rather, it was a place where prisoners awaited sentencing. As before, Philip was determined to remain apart from the regular prison population. He became a stool pigeon for the district attorney. Politics again came into play, and Philip, in an effort to gain favor with authorities, doctored a petition by the prisoners that probably resulted in the death by execution of a prisoner. While in the Tombs, Philip also "befriended" another prisoner Hans Schmidt, a fake priest accused of murdering a servant girl during a botched abortion and sawing her into pieces that he could carry and drop into the Hudson River. Philip coached Hans on how to behave in public so that he might be able to use an insanity defense. Musica then told the prosecution that Hans had been studying the insanity defense in law books. Hans was executed, and Philip left the Tombs with a suspended sentence.

\section{THE SPY - WILLIAM JOHNSON}

Using the name William Johnson, Philip now became a special investigator for the Attorney General of New York. Once again, Musica sought to please those with power and, using bribery and perjury, helped convict Joseph Cohen, an innocent man, of murder. The plot came to light, and Philip was indicted for subornation of perjury. Using his personal charm, he kept his case from ever going to trial. Joseph Cohen, having been within seven minutes of death by electrocution was freed from prison only to be shot and killed in his own doorway by three men who were never caught.

\section{FRANK COSTA AND ADELPHI PHARMACEUTICAL}

In 1919, when Philip was 34 years old. Ever the entrepreneur, he embarked on a new enterprise. When the 18th Amendment was ratified by Nebraska on January 16, 1919, Prohibition was on the way. The Volstead Act was passed in October 1919 to enforce the amendment. President Woodrow Wilson vetoed the Act, but Congress passed it over the President's veto. On January 17, 1920, the United States went dry. It was now against the law to buy, sell, or drink intoxicating beverages. Illegal stills and speakeasies became sources of immense revenues as Americans looked for liquor outside the law.

Philip, now operating under the name of Frank B. Costa, entered into a partnership with a man he had met in prison and began Adelphi Pharmaceutical Manufacturing Company in Brooklyn. On the surface Adelphi Pharmaceutical manufactured hair tonic and cosmetic. For these products, the company was able to legally draw 5,000 gallons of denatured alcohol a month. If customers, in turn, distilled the alcohol from the hair tonic and other products, which could then be sold as bootleg whiskey, clearly Adelphi was not at fault.

While Adelphi was proceeding at full capacity, Philip turned his attentions elsewhere. He met and fell for the wife of a Wall Street investor, Edward Hubbard. Methodically, Philip set out first to destroy Edward's business and then to drive Edward himself to a mental breakdown. Once Hubbard was out of the picture, Philip would be free to woo and wed Edward's former wife, Carol. Carol, who appeared to be a good wife to Edward and an innocent bystander to what was happening, would remain a faithful wife to Philip for the rest of his life, content to remain at their home in Fairfield and raise prize-winning chow dogs.

Having won his beloved, Philip now cut his ties with Adelphi Pharmaceutical. He informed his partners that he was withdrawing. When they refused to allow this knowing that they were unable to carry on the business as successfully without Costa, a note informing the federal enforcers of the Volstead Act that the company's products were being diverted to illegal alcohol quickly brought the company to its knees leaving Philip to follow other pursuits. 


\section{DR. F. DONALD COSTER AND MCKESSON \& ROBBINS}

In 1923, Philip, now using the name of Dr. F. Donald Coster (supposedly with a Ph.D. and MD from the University of Heidelberg), along with George Dietrich (actually brother George Musica), and P. Horace Girard (brother Robert Musica) began Girard \& Co. in Mount Vernon, New York. One of Girard's largest subsidiaries would be W.W. Smith \& Co. under the leadership of George Vernard (brother Arthur Musica).

Staying with what President Coster knew was a proven success, Girard \& Co. produced products such as hair tonics, colognes, and furniture polish that had high alcohol content enabling Girard \& Co. to draw 5,200 gallons of alcohol a month. Some products had as much as a $90 \%$ alcohol content, which made them highly desirable to bootleggers. Other products were of such high quality that they could compete with other legitimate products in drugstores, retail outlets and pharmaceutical distributors. The company did well on paper even though perhaps only half of its actual revenues were reflected on the books. Girard requested a larger alcohol allotment. Enforcers of the Volstead Act found the records of the company to be in perfect order. The company's alcohol allowance was increased to 25,000 gallons a month.

Price, Waterhouse \& Co. (the predecessor of PricewaterhouseCoopers) was selected as auditor in 1925 at a fee of $\$ 550$. Coster (Philip) knew that auditors did not examine accounts receivable and inventories directly but rather relied on paper documents such as purchase orders, customer orders, receiving reports, and shipping documents. ${ }^{7}$

Looking to expand Girard, Coster met Julian F. Thomson, a banker with Bond \& Goodwin. (Thompson would later become the treasurer of McKesson \& Robbins, Inc.) Thompson was impressed not just with Girard, but also with Coster himself. With a move to the Gold Coast of Fairfield County in Connecticut, Coster found more and more top banking officers coming under his spell. He entertained them aboard his 125-foot yacht, the Carolita, and they lent Girard Company money and invested their personal funds in its common stock. They adored Coster, and "[a]s a reward he gave them profits in such gratifying ratio to their investments that they were too dazzled to be curious. They had discovered a singular genius, and their faith in him was faith in themselves. They clasped him to their bosoms and invited him to join their most exclusive clubs."

Dr. Coster turned his attentions to his personal life. He purchased an 18-room mansion in Fairfield. He decorated it with a life-size portrait of Theodore Roosevelt, a library, an Oriental room, a sun room, a poolroom with a slot machine, wine cellars stocked with "pre-Prohibition American ryes and bourbons, available only on physicians' prescriptions," and a recreation room that could seat one hundred guests. Next, Dr. Coster married his love, Carol Jenkins Hubbard, on May 1, 1926. For his marriage license, Philip altered only a few facts, including his place of residence (New York rather than Fairfield), his parents' name (from Antonio and Assunta Musica to Anthony and Assumption Girard Coster), and their place of birth (from Italy to the United States). ${ }^{10}$

As with Adelphi, Girard \& Co. soon grew too small for Dr. Coster. He began to eye McKesson \& Robbins, a nearly 100 year old pharmaceutical company. Though old and respected, by 1924, disagreement had grown among the heirs of John McKesson Jr., and the company had split into New York Quinine and Chemical Works and McKesson \& Robbins. The McKesson \& Robbins portion had dropped its distribution business and the volume of the company's business began a downward slide until the owners reached the point where they would accept any reasonable offer for the firm. Coster bought the firm for $\$ 1,000,000$ in the fall of 1926, moved it to Fairfield, and then sold $\$ 1,650,000$ of stock in his new company - McKesson \& Robbins of Connecticut.

\footnotetext{
${ }^{7}$ Keats, pp. 19-72.

${ }^{8}$ Keats, p. 76.

${ }^{9}$ Keats, p. 80.

10 Clearly, Philip Musica was not satisfied with his history. In 1935, he had a birth certificate filed on which he changed his birthplace (from New York to Washington, D.C.), his mother's name (from Assunta or Assumption to Marie). A year later, when named to Who's Who, his parents became Frank Donald and Marie Girard Coster, his date of marriage was pushed back five years to a point two years before his wife had divorced her first husband, and her maiden name changed from Jenkins to Schieffelin. (Keats, pp. 80-81.)
} 


\section{THE DIETRICHS AND THE FRAUD}

Repeating a familiar pattern, McKesson \& Robbins quickly became a family affair. George Dietrich (brother George) was named assistant treasurer and Robert Dietrich (brother Robert) directed the shipping department. The New York office of McKesson \& Robbins was located in a building owned by Assumption Coster (Mama Assunta). George Vernard (brother Arthur) played critical roles as well, becoming head of Philip's private bank, Manning \& Co., and remaining head of W.W. Smith \& Co. ${ }^{11}$ Much of McKesson \& Robbins's fraudulent crude drug activities took place in the Brooklyn office of W.W. Smith where "...Arthur Musica prepared all correspondence for the fictitious companies with which the McKesson corporation was supposedly dealing... [using] ...a number of different typewriters, each of which was used for the typing of documents for one specific dummy corporation." 12 To maintain distance between the companies, Most of the documents prepared in the Brooklyn office were then sent to an "office" in Montreal where a typist opened each piece of incoming correspondence, placed it in another envelope, and mailed it to Philip at McKesson \& Robbins in New York. Philip, as Dr. Coster, answered the correspondence and routed it back to Montreal. Five other associated fictitious crude drug wholesalers and a fictitious bank likewise were created in Canada and operated in a similar manner.

The bootlegging operations of Girard \& Co. also continued under McKesson \& Robbins. Its tincture of iodine was a particularly prized product. However, an iodine trust in Chile existed that made it difficult for Coster to receive the iodine he needed on the best terms. Philip set out to break the monopolistic hold the Chilean trust had on iodine. Successful in that venture, he proceeded to break the quinine monopoly in the Netherlands and the bismuth monopoly in Bolivia. Having shown his ability to play in the international markets, Dr. Coster was ready for the final big deal - a corporation trading internationally in crude drugs, McKesson \& Robbins, Ltd. In less than one year, Dr. Coster had turned McKesson \& Robbins around from a company losing money to one showing a $\$ 600,000$ profit including the effects of hefty receivables and inventories in the Canadian subsidiaries.

By 1927 , McKesson \& Robbins was a $\$ 4,000,000$ company. The stock market was booming. Dr. Coster was ready for the next step - Wall Street. He called Julian Thompson, the banker who had been so awed with Dr. Coster when they had first met in Connecticut. Thompson was asked to approach regional drug distributors to consolidate their operations into the McKesson \& Robbins distribution operations in exchange for stock in McKesson \& Robbins of Maryland. Coster promised economies of scale from the consolidation; however, he did not mention that there was also consolidation of power into his hands.

George Dietrich (brother George) handled all correspondence from the company's Canadian subsidiary. Every morning he opened all letters, even those for his superior, Julian Thompson, supposedly because George was an ardent stamp collector and wanted all those colorful foreign stamps. ${ }^{13}$ On paper, the subsidiary traded millions of dollars worth of crude drugs worldwide, but no drugs ever changed hands. W.W. Smith \& Company made "sales" to fictitious companies around the world and notified McKesson \& Robbins of the sales and shipments where an invoice was typed. The invoices were sent to Brother George for mailing and were probably destroyed by him. W.W. Smith "collected" on the invoice and "deposited" the funds in Philip's fictitious Canadian bank, Manning \& Company. The bank notified the accounting department of McKesson \& Robbins of the collections and deposits so that proper accounting entries could be made. Of course, it was impossible for the Canadian office of W.W. Smith to funnel back any of the funds to McKesson \& Robbins for use in regular operating activities since no cash had ever been collected. This failure to send back funds was explained by the build-up of fictitious inventories in Canadian warehouses. ${ }^{14}$

\footnotetext{
${ }^{11}$ Keats, pp. 85-95.

${ }^{12}$ Flaa, p. 11.

${ }^{13}$ Keats, pp. 85-108.

${ }^{14}$ Flaa, pp. 11-14.
} 


\section{THE BEGINNING OF THE END}

In 1928, Americans were riding high, but the fall was coming. Warnings went unheeded by “...people who arose each morning confident that they would be millionaires by suppertime." 15

Dr. F. Donald Coster had accounts with several brokers in several names including an "uncle" P. Horace Girard. Coster offered 20,000 shares of dying Uncle Horace's shares to two investment bankers for $\$ 500,000$. Seeing others whose investments of as little as \$20,000 with Coster in Girard \& Co. in 1926 had grown to more than $\$ 1,000,000$ in only two short years, the bankers were delighted and no one seemed to notice either that the name on the stock was not Uncle Horace or that the check went to Dr. Coster personally. ${ }^{16}$

Suddenly McKesson \& Robbins was charged with violating the Clayton Antitrust Act because the acquisition of the smaller wholesale drug firms had reduced competition and "created a monopoly in certain drugs and proprietary medicines." ${ }^{17}$ As had happened so mysteriously before in Philip's life, as suddenly as they had appeared, the Federal Trade Commission charges were just as quickly dropped.

Then came Terrible Tuesday, October 29, 1929. Coster was worth an estimated $\$ 6,500,000$ at that time. Like other investors, Coster was invested on the margin and faced margin calls. He had George Dietrich (brother George at McKesson \& Robbins) issue cash to W.W. Smith (George Venard, aka brother Arthur) supposedly to cover purchases of crude drugs by the Canadian subsidiary. Instead of covering purchased, Dr. Coster used McKesson \& Robbins funds in the amount of $\$ 634,000$ to cover margin calls on his private accounts.

Although many of his actions were fraudulent, Coster worked tirelessly to keep McKesson \& Robbins solvent. The company shuddered in the wake of the stock market's freefall, but thanks in part to the fake receivables and inventories of the Canadian subsidiary, the company stood. Coster also looked for other ways to prop up McKesson \& Robbins during these difficult times - some legitimate, others less so. He bought drugs from bankrupt pharmaceutical companies at low prices then booked them in inventory at highly inflated prices. He used the press to plant favorable articles about the company. Without using scarce McKesson \& Robbins cash, he cornered a 25 year supply of cod liver oil in exchange for stock. In addition, because Prohibition continued and America remained dry, the bootlegging went on.

The Canadian operations also continued. Paperwork was accurate and detailed. Basically, when a purchase was planned, McKesson \& Robbins, upon receipt of the proper paperwork - purchase order, invoice, receipt tick, and debit memo from Manning \& Co. (Coster's private bank) that the vendor had been paid - would issue the check. Sales were likewise supported on paper; the difference was that the receipts from the customer were in the forms of increases in receivables, increases in inventory, or payments to the Manning account. W.W. Smith was paid a basis fee of $\$ 18,000$ per year plus $0.0075 \%$ of sales. All monies, an estimated $\$ 120,000,000$ over ten years, however, ultimately moved in and out of the hands of Philip Musica.

Yet all the carefully documented transactions were a hoax. How, one wonders, could the auditors have missed this for so long? No one seemed to notice that “... there were not enough Himalayan musk deer in the world to fill the orders placed..." or "... that vanilla beans are shipped in tins and not in 200-pound bags like lima beans..." or "...that the amount of procaine or iodoform supposedly stored in Canadian warehouses would supply the entire United States for years..." or that merchandise was moved "...from South America to Australia and China 'by truck."” 18

The SEC was later to ask similar questions and to state:

\footnotetext{
${ }^{15}$ Keats, p. 110.

${ }^{16}$ Keats, pp. $75-111$.

${ }^{17}$ Keats 111.

${ }^{18}$ Keats, pp. 112-119, quote from p. 119.
} 
The firm of Price Waterhouse \& Co. for 14 years served as independent public accountants for F. Donald Coster's [Philip Musica's] enterprises. Within [the] range of the procedures which they followed there were numerous circumstances which, if they had been recognized and carefully investigated by resourceful auditors, should have revealed the gross inflation in the accounts. We are convinced that despite collusion and skillfully prepared false documents [,] these items repeated themselves to such an extent as to have permitted detection of the gross inflation by alert auditors intent upon knowing the truth about the foreign crude drug operations. ${ }^{19}$

Perhaps part of the answer lies in a 1933 letter from Coster to Price Waterhouse Co.:

Incidentally, our comptroller has called my attention to the fact that payments for auditing fees paid by us since organization to your good firm have reached the million mark. I am very glad of it and feel that among the major expenses incidental to mergers and consolidations only in auditing did our company really get its money's worth. ${ }^{20}$

When Franklin D. Roosevelt was elected in 1932, Coster, an avowed Republican, could see the end of prohibition on the horizon. Knowing that the profits of illegal liquor would soon come to an end, Coster prepared for the coming change. He sent Julian Thompson abroad to secure contracts for the finest wines and liquors. On December 5, 1933, when Utah ratified the 21st Amendment that repealed the 18th Amendment and the Volstead Act, Coster and McKesson \& Robbins were ready - ready with 66 distributors that had come on board and ready with bootleggers who were ready to become dealers in legitimate liquor. Sales boomed.

Over the next year or so, there were rumblings against Coster. Some stockholders grew weary of his autocratic control of the company; some questioned why the profits of the Canadian subsidiary were always plowed back into inventory rather than being returned to the United States. Coster withstood the storms and retained control of the company.

One of the strangest events in the history of McKesson \& Robbins was the Lee-Enfield rifle affair. Somehow Coster arranged to purchase hundreds of thousands of World War I surplus rifles stored in government warehouses. Although there was talk of possible sales to Chiang Kai-shek, Benito Mussolini, Forces in Spain, and the Mexican government, no one seems certain of whatever became of the rifles. ${ }^{21}$ After his death, a federal investigation placed in doubt the possibility that Coster would have been able to purchase the rumored 250,000 rifles and the matter subsequently was dropped. ${ }^{22}$

\section{THE END DRAWS NEARER}

What happened to bring down the façade that was the Canadian subsidiary? In 1937, Thompson began to look askance at the operation. It was the most profitable division of the company, yet all profits were plowed back into crude drug inventories. Receivables and inventories combined for $\$ 18,000,000$ of McKesson \& Robbins total of $\$ 80,000,000$ in assets.

Thompson asked Coster to bring some of the profits back to reduce the company debt. As would so often be his response in the future, Coster rejected Thompson's request.

A decrease in inventories should result in an increase in cash or receivables when the inventories were sold. Since those inventories were fictitious and their decrease would result in no cash to return to McKesson \& Robbins, Coster was in a desperate position. Thompson approached other directors who chose to attack the problem by voting to reduce all company inventories by $\$ 4,000,000$ including a $\$ 1,000,000$ reduction in the crude drug

\footnotetext{
${ }^{19}$ Pollack and Sporkin, pp. 10-11 quoting from Report on Investigation Pursuant to Section 21(a) of the Securities Exchange Act of 1934 in the Matter of McKesson \& Robbins, Inc. (1940), p. 438-439.

${ }^{20}$ Keats, p. 119.

${ }^{21}$ Keats, pp. 123-152.

22 “Coster Arms Deal...", p. 12.
} 
inventories in the Canadian warehouses. Coster seemed to accept the board's decision, but by the following year, the Canadian inventories were even larger.

During the summer, Thompson suggested that he would visit the Canadian warehouses while on vacation with his family in Poland Springs, Maine. While Coster seemed to agree to this action, he called Thompson back to Fairfield every few days for meetings. His suspicions aroused, Thompson began to dig. He found that Coster had not reduced the crude-drug inventories and that there was no insurance on the inventory. Coster tried to explain this away by saying that W.W. Smith insured the inventory. Coster said the interest in the subsidiary was an attempt to take his job as president away.

Thompson's suspicions were heightened when he noticed that the fees to W.W. Smith were paid by McKesson \& Robbins rather than from the profits of the Canadian subsidiary. As treasurer, Thompson had seen the Dun \& Bradstreet reports on W.W. Smith each year as part of the audit report. He requested a copy of the latest Dun \& Bradstreet report on the firm from a New York attorney. Imagine his surprise when he learned Dun \& Bradstreet had no reports on the company. Thompson then went to Price, Waterhouse and got file copies of the last two Dun \& Bradstreet reports on W.W. Smith, which, incidentally, the auditors indicated had been supplied by George Dietrich. Returning to Dun \& Bradstreet with the photocopies, Thompson learned that the copies were forgeries. Continuing his quest, Thompson's inquiries in Montreal provided information that the main business of W.W. Smith was conducted in Liverpool while inquiries in Liverpool indicated that the main business was conducted in Montreal. Furthermore, bankers in both cities were unaware of the company.

Events now began to move rapidly. Thompson was ready to confront Coster again. Coster called Thompson in to discuss floating a $\$ 3,000,000$ bond issue. After that discussion, Thompson turned to the problem of W.W. Smith. Again, Coster brought up the prospect of a conspiracy to take away his job, but that he would get the records together in a day or so. When Coster was ill the next day, Thompson set out on his own to visit the offices of W.W. Smith in Brooklyn. There he found the names of both W.W. Smith and Manning on the door. Inside he found a receptionist and a drunken George Vernard (brother Arthur). When Thompson left, Vernard phoned George Dietrich who informed Coster. Coster ordered George to remove incriminating documents from the company safe.

The following day, Thompson again faced Coster. Coster, actually still ill with a throat infection, demanded that Thompson resign. Thompson refused. On December 5, 1938, Thompson telephone Coster and told him he was bringing the information to the executive committee of McKesson \& Robbins as soon as possible. ${ }^{23}$

At almost the same time, Vincent W. Dennis, a stockholder of only a few hours, filed an action to place McKesson \& Robbins into receivership until the question of some $\$ 20,000,000$ in missing assets could be settled. Receivers were appointed. They immediately placed locks on the company safe not knowing that George already had removed at Philip's command all documents of importance much earlier.

The executive committee of McKesson \& Robbins responded quickly by calling in the SEC and asking it to investigate financial statements that might possibly be fraudulent. They then called in the senior partner of Price, Waterhouse who assured the worried committee members that the financial statements were in order. Next, the committee contacted the New York Stock Exchange to ask that trading in McKesson \& Robbins stock be halted. (Coster had anticipated this and had liquidated some of his holdings earlier.) Trading of McKesson \& Robbins stock was halted at 11:30 A.M. on December 6, 1938. Then the committee sat and waited for Coster to make a promised appearance at the office. Coster called and said he could not come. Thompson and the others filed a petition for reorganization stating that "information has come to light...indicating that the inventories and accounts receivable relating to the crude-drug business have been overstated for a substantial period and the current position of the petitioner [McKesson \& Robbins] as appears on the balance sheet is false and misleading." The petition was granted giving McKesson \& Robbins the dubious honor of being the "first major corporation to enter reorganization under Chapter X of the Chandler Act...."24

\footnotetext{
${ }^{23}$ Keats, pp. 163-174.

${ }^{24}$ Keats, pp. 181-182.
} 
The receivers who were appointed, tried to calm fears of the public regarding the solvency of McKesson \& Robbins. The executive committee went to court asking that the receivers be removed since they were from Connecticut and were probably under the influence of Coster. ${ }^{25}$ The judge agreed and two new trustees were appointed. The trustees were to:

1. ...prepare a reorganization plan acceptable to the creditors, the stockholders, Judge Coxe, and the Securities and Exchange Commission.

2. ...run the business without interference by the stockholders as long as the firm remained in reorganization.

3. $\quad$...recover all missing assets. ${ }^{26}$

Since the financial statements showed assets of $\$ 86,500,000$; liabilities of $\$ 76,250,000$; and that missing assets were expected to be $\$ 10,000,000$, it appeared that the company was solvent. A federal judge tied up accounts of Coster and his wife, Carol, valued at approximately $\$ 100,000$ each.

Everyone jumped into the fray - at least eight separate investigations-federal, state, and city, were simultaneously on-going. When the dust had settled, Price, Waterhouse, Coster's auditor since as early as 1925 admitted to not having visited any of the crude drug warehouses in Canada even though the inventories there constituted nearly one-eighth of McKesson \& Robbins's assets. None of the prestigious firms with which the Canadian subsidiaries of McKesson \& Robbins were supposed to have been doing business had any records of any transactions with the company. The fraud had been perpetuated by the Musicas using a series of mail-drop "warehouses" staffed by ladies paid as little as $\$ 7.50$ per week.

On December $12^{\text {th }}$, Thompson and the board called on Coster and George Dietrich to resign. This Coster could not do; he had spent too much of himself developing the persona of F. Donald Coster to surrender to his enemies. On December $13^{\text {th }}$, an agent of the SEC asked for the arrest of F. Donald Coster, George Dietrich, and George Vernard for filing false information. Coster claimed to be too ill to leave home and come to New York. It was agreed that he and brother George would surrender at Coster's home in Fairfield. On December $14^{\text {th }}$, federal officials, Coster's attorney, brother George and at least 20 reporters and photographers assembled in the library of Coster's home. Waiving the reading of the charges, Coster and Dietrich were informed that they were under arrest. Both were fingerprinted and freed on $\$ 5,000$ bond to be paid later in the day. Both were charged with filing false information with the SEC, which, if they were found guilty, would earn them a $\$ 10,000$, fine, a term of up to two years in prison or both.

Armed with the fingerprints, the entire story now threatened to break. An investigator in the New York attorney general's office thought he recognized Coster as William Johnson who had worked undercover with the attorney general's office in 1917 and whose real name was Philip Musica. He also remembered Philip's criminal past. A set of fingerprints from over 20 years earlier was found, but they were blurred and unusable. More surprising (or perhaps not surprising at all), the rest of the dossier on Philip Musica in the office of the attorney general had disappeared.

Meanwhile, other memories were jogged. Members of the press noticed the resemblance of Coster to the son of an Italian immigrant who had been involved in a cheese scandal in 1909 and a human hair fraud in 1913. The quest was on for the true identity of F. Donald Coster. When it seemed that the search would be unsuccessful, Inspector James J. Donovan remembered that there were duplicate files of many old cases in a station house on the lower east side. A six-hour search finally yielded results and a few minutes before midnight on December 15 , Inspector Donovan announced to the press "that Dr. F. Donald Coster, the financial wizard and president of the vast McKesson \& Robbins pharmaceutical empire, and Philip Musica, the twice guilty swindler from Mulberry Bend, were one and the same person.,"27

\footnotetext{
${ }^{25}$ Keats, pp.175-182.

${ }^{26}$ Keats, p. 182.

${ }^{27}$ Keats, pp. 182-200, quote from p. 200.
} 
Alone in his study of his home the following morning, Philip Musica did again what he had done so often before. Claiming loyalty to the company rather than personal enrichment as the reason for his actions, Philip wrote the story of the McKesson \& Robbins scandal admitting to inflating profits in order to save the company, accepting full blame for everything that had happened, and absolving everyone else from any responsibility. He placed the letter in an envelope for his attorney.

Meanwhile, Carol, Philip's wife, fearing what he might do had enlisted the aid of the butler and gardener to hide all the guns in the house. When the gardener found some of the guns he had hidden had been removed, he reported this to Ms. Coster. Carol, in turn, begged her husband to turn the guns over to her. Coster refused saying that he needed them in case "that two-faced Thompson" showed up.

The next morning Philip arose, dressed in a bathrobe, and placed a revolved in the pocket. He wandered through the house for hours drinking highballs. A few minutes before noon a call came from brother George's house that George was under arrest and federal agents were headed to Philip's house. Philip went upstairs to a window where he could watch the agents come up the driveway. The family's St. Bernard began to bark at the approach of strangers and Carol awoke and went downstairs. Philip removed the revolver from the bathrobe pocket and placed it against his head. At 12:09 on Friday, December 16, 1938, a federal marshal rang the doorbell and Philip pulled the trigger. The president of McKesson \& Robbins was dead. By the end of the day the remaining Musica brothers would be under arrest.

\section{THE AFTERMATH}

When trading in McKesson \& Robbins stock was resumed, the effect of all these events was apparent in the stock price. The stock, which had been at $7 \frac{1 / 2}{2}$ before trading was suspended, fell to 50 cents. The proud old company was the subject of rumors and allegations. The story of the Enfield rifles led to stories of meetings with foreign leaders and financing of foreign wars.

As time passed, under new leadership and in the turbulent prewar economy, McKesson \& Robbins recovered and became profitable once more. But the story of F. Donald Coster went on. Stories of a diary and a "little brown book" surfaced. The book was suppose to contain information on police, politicians, as well as underworld figures like Al Capone and Dutch Schultz who had been blackmailing Coster leading to his need for funds. It was rumored that Coster was paying as much as $\$ 25,000$ per year to keep quiet those who had known him in his earlier lives as Philip Musica or Frank Costa. ${ }^{28}$

Eventually interest in the "little brown book" waned as the trials began with the prosecution indicting only nine people, including the three Musica brothers, in the swindle. Six of the defendants pled guilty; three went to trial. Despite nearly two tons of documents, the prosecution case was weak The most important witness, Julian Thompson, who had initially sponsored Dr. Coster and then had been the first to seriously doubt him, became severely upset by the situation. He finally weakened to the point that he caught a cold that developed into pneumonia, and died on April 21, 1939, after only being ill for one week. His estate was valued at $\$ 41,000{ }^{29}$

During the trial, the prosecution tried to show that Coster was "'a small-timer of unsavory reputation who could not have got to first base in this huge swindle without the aid of these men [the defendants].... Investigations ...revealed that this was not a one-man show at all. Coster had help, plenty of help." 30 The defense tried to place total blame on the financial wizard and show that Coster was the mastermind while the defendants were simply following orders and "were not intelligent enough to keep pace with Coster."31 Testimony showed that in the last year of Coster's leadership, McKesson \& Robbins was actually profitable based on its $\$ 150,000,000$ of legitimate sales and only $\$ 19,000,000$ in fictitious sales.

\footnotetext{
${ }^{28}$ Sifakis, p. 134.

${ }^{29}$ Keats, pp. 200-228.

${ }^{30}$ Keats, pp. 231.

${ }^{31}$ Keats, pp. 232.
} 
The trial lasted ten weeks, the charge to the jury lasted two hours; the jury deliberated thirteen hours and reached a verdict on two of the nine defendants. Rowley W. Phillips and Horace Merwin, both Connecticut bankers were found not guilty on all counts. Forty-five minutes later, John H. McGloon, the comptroller of McKesson and Robbins was found guilty on one of 13 counts. For violation of the Securities and Exchange Act he was sentenced to one year and one day in prison and a \$5,000 fine. As for the other six defendants who had pled guilty, Benjamin Simon was sentenced to three years, John and Leonard Jenkins, two brothers-in-law, were sentenced to one year and one day, but Leonard's sentence was suspended. Of the three Musica brothers, George Vernard (brother Arthur) was sentenced to three years, George Dietrich (brother George) to two and one-half years, and Robert Dietrich (brother Robert) to one and one-half years. ${ }^{32}$

Price, Waterhouse returned over $\$ 550,000$ of the fees it had collected over the years.

How much was lost? Estimates vary from $\$ 3,000,000$ and $\$ 18,000,000$. Fake sales resulted in fake receivables, which were paid with non-existent cash that was deposited in a fake bank and then used to purchase fake inventories. The cash loses seem to be limited to approximately, $\$ 150,000$ in commissions and an $\$ 18,000$ annual fee paid to W.W. Smith \& Co. and an annual \$12,000 fee paid to Manning \& Co. Has Coster left a clue? In his suicide note, Coster stated in part:

McKesson should have been in receivership in 1930 and again in 1932 if its profits had not been bolstered in a frantic effort to save the company from the hands of the bondholder. In other words, in the main there were cash sales to create a profit that did not exist, and what is missing is the alleged profits plus expenses and blackmail money paid to maintain it. As God is my judge I am the victim of Wall Street blunder and blackmail in a struggle for honest existence. ${ }^{33}$

So what happened to the remaining cash? Musica's estate was valued at less than $\$ 40,000 .{ }^{34}$ Some people pointed back to blackmail based on the "little brown book", suggesting that the names it contained were so prominent that the entire contents needed to be suppressed. One former bootlegging partner, Mary Brandino, was actually indicted for blackmailing Musica. When the delirious Dutch Schultz lay dying following being shot by assassins in New Jersey in 1935, he mentioned a Phil and a George. Some thought he might have been speaking of Frank Coster and George Dietrich. People dug at night around Fairfield, including under the St. Bernard's doghouse looking for the lost treasure of Philip Musica. There are probably those who are still looking some seventy years later.

What of the other members of the cast of characters? Wife Carol remarried in 1949, sold the mansion, and moved to Florida. Mama Assunta was too ill to be told of her son's death by suicide. She died in Long Island in October 1941,three years after her son. Robert Dietrich was released from prison in August 1941. He went to work for Suburban Leather Goods Company in Brooklyn and died in New Rochelle, New York, in 1956. George Dietrich was released in 1942 and returned to Fairfield and worked for Grasmere Development Company. He died on Long Island in 1947. George Vernard also was released from prison in 1942 and disappeared from public view. ${ }^{35}$

\section{THE REACTION OF THE PROFESSION - INVENTORIES}

Physical examination of inventories was not required under generally accepted auditing procedures of the day. In 1936, in its Examination of Financial Statements by Independent Public Accountants, The American Institute of Accountants (AIA), later to become the American Institute of Certified Public Accountants Institute, had stated that the examining accountant"...must rely principally for information as to quantities, quality and condition upon the responsible officers and employees of the company." However, the Institute went on to state that the

\footnotetext{
${ }^{32}$ Keats, pp. 232-236.

33 "No Hidden Treasures," p. 30.

${ }^{34}$ Flaa, p. 18.

${ }^{35}$ Keats, pp. 238-252.
} 
accountant must "[m]ake reasonable inquiries and tests to ascertain that quantities have been carefully determined and that quality and condition have received due consideration." 36

The examining accountants did a limited physical examination of the wholesale division, which constituted approximately $70 \%$ of the total inventories of McKesson \& Robbins. However, the examining accountants from Price, Waterhouse relied entirely upon statements of management (the Musicas) and documents, including confirmations (all prepared by brother Arthur) for the inventories of the Canadian subsidiaries.

In addition to the federal, state, and local investigations into the McKesson \& Robbins fraud and the history of the Costers and the Dietrichs, the AIA adopted measures extending generally accepted auditing procedures especially in regard to inventories and receivables.

The SEC began hearings on the case on January 5, 1939, less than three weeks after the suicide of Philip Musica, with the purpose of determining:

1. the character, detail and scope of the audit procedures followed by Price, Waterhouse \& Co. in the preparation of the financial statements...;

2. the extent to which prevailing and generally accepted standards and requirements of audit procedures were adhered to and applied by Price Waterhouse \& Co. in the preparation of the financial statements; and,

3. the adequacy of the safeguards inhering in the generally accepted practices and principles of audit procedure to assure reliability and accuracy of financial statements. ${ }^{37}$

Even with the facts of McKesson \& Robbins before them and perhaps because of the exceptional amount of collusion among the principals of this company, many of those who testified still felt that the cost of a physical inspection of inventory outweighed the benefit. However, the SEC, in its review concluded, in part, that "...the audits performed by Price, Waterhouse \& Co. substantially conformed, in form, as to the scope and procedures employed, to what was generally considered mandatory during the period of the Girard-McKesson engagements. ${ }^{38}$ Regarding inventories, the SEC found that the "audit program for the verification of inventories was essentially that which was prescribed by generally accepted auditing practices for the period.... [and] took the position that the verification of quantities, quality, and condition of inventories should be confined to the records.... Meticulous verification of the inventory was not needed in this case to discover the fraud.... We commend the action of the profession in subsequently adopting, as normal, procedures requiring physical contact with clients' inventories. ${ }^{39}$

The action to which the SEC referred was the profession's "Extensions of Auditing Procedure" in 1941. The extended recommendations made by the AIA included:

A. That hereafter, where the independent certified public accountant intends to report over his signature on the financial statements of a concern in which inventories are a material factor, it should be generally accepted auditing procedure that, in addition to making auditing tests and checks of the inventory accounts and records, he shall, wherever practicable and reasonable, be present, either in person or by his representatives, at the inventory-taking and by suitable observation and inquiry satisfy himself as to the effectiveness of the methods of inventory-taking and as to the measure of reliance which may be placed upon the client's representations as to inventories and upon the records thereof. In this connection the independent certified public accountant may require physical tests of inventories to be made under his observation.

In cases where the inventory is determined solely by means of a physical inventory at the end of the accounting period (or at a date prior or subsequent thereto but within a reasonable time thereof, with adequate records supporting the interim changes), it will ordinarily be necessary for the foregoing procedures to be followed at that time...

B. That hereafter, in the case of inventories which in the ordinary course of business are in the hands of public warehouses or other outside custodians, direct confirmation in writing from such custodians is acceptable

\footnotetext{
${ }^{36}$ American Institute of Accountants, pp. 6-7.

${ }^{37}$ S.E.C., Accounting Series Releases..., p. 4.

${ }^{38}$ S.E.C., Accounting Series Releases.... p. 9

${ }^{39}$ S.E.C., Accounting Series Releases..., p. 8.
} 
procedure, except that, where the amount involved represents a significant proportion of the current assets or of the total assets of a concern, the independent certified public accountant shall make supplementary inquires.

It should be clearly understood that in undertaking these auditing procedures regarding inventories, the independent public accountant does so for the purpose of satisfying himself as to the credibility of the representations of the management regarding quantity and condition and does not hold himself out as a general appraiser, valuer, or expert, in materials. ${ }^{40}$

Just as with inventories, Price, Waterhouse followed generally accepted auditing procedures of the day with respect to accounts receivable which did not require confirmation even if receivables were material. In this case, the examining accountants accepted information from within McKesson \& Robbins rather than confirming receivables with customers of the crude drug division. Again, following the SEC hearings where witnesses discussed the pros and cons of confirming, the AIA also addressed this issue stating:

That hereafter, whenever practicable and reasonable, and where the aggregate amount of notes and accounts receivable represents a significant proportion of the current assets or of the total assets of a concern, confirmation of notes and accounts receivable by direct communication with the debtors shall be regarded as generally accepted auditing procedure in the examination of the accounts of a concern whose financial statements are accompanied by an independent certified public accountant's report... ${ }^{41}$

\section{OTHER OUTCOMES}

The SEC was also concerned about the method and timing of the appointment of auditors in McKesson \& Robbins and the form of the audit report. The officers of McKesson \& Robbins generally appointed its auditors late in the year, which restricted the amount of time available for the audit to be performed. The SEC recommended instead that:

1. Election of the auditors for the current year by a vote of the stockholders at the annual meeting followed immediately by notice to the auditors of their appointment.

2. Establishment of a committee to be selected from nonofficer members of the board of directors which shall make all company or management nominations of auditors and shall be charged with the duty of arranging the details of the engagement.

3. The certificate (sometimes called short-form report or opinion) should be addressed to the stockholders. All other reports should be addressed to the board of directors, and copies delivered by the auditors to each member of the board.

4. The auditors should be required to attend meetings of the stockholders at which their report is presented to answer questions thereon, to state whether or not they have been given all the information and access to all the books and records which they required, and to have the right to make any statement or explanation they desire with respect to the accounts.

5. If for any reason the auditors do not complete the engagement and render a report thereon, they shall, nevertheless, render a report on the amount of work they have done and the reasons for noncompletion, which report should be sent by the company to all stockholders. ${ }^{42}$

The SEC also looked at the form of certificate issued by the examining accountants at the time and determined that it

\footnotetext{
${ }^{40}$ AIA, "Extensions of Auditing Procedure," pp. 6-7. Another result of these extensions was that both the SEC and the AIA encouraged businesses to adopt a "natural business year" rather than adhering to the general practice of using a calendar. It was thought that this would give a more complete fiscal picture of the business and allow accountants to distribute their workloads, now increased by these new inventory requirements, over the year.

${ }^{41}$ AIA, "Extensions of Auditing Procedure," pp. 7-8.

${ }^{42}$ SEC, Accounting Series Releases..., pp. 6-7.
} 
"....should be amended to include in addition to the description of the scope of the audit a clear certification that the audit performed was, or was not, adequate for the purpose of expressing an independent opinion in respect to the financial statements. If any generally accepted procedures are omitted these should be named together with the reasons for their omission. Exceptions to the scope of the audit or to the accounts must be cleared designated as "exceptions." 43

Again, the profession responded, and the AIA recommended the use of a standard revised report to include both an explanation of the scope of the work done and an emphasis on the auditor's evaluation of the internal control within the company:

We have examined the balance sheet of the XYZ Company as of April 30, 1939, and the statements of income and surplus for the fiscal year then ended, have reviewed the system of internal control and the accounting procedures of the company and, without making a detailed audit of the transactions, have examined or tested accounting records of the company and other supporting evidence by methods and to the extent we deemed appropriate.

In our opinion, the accompanying balance-sheet and related statements of income and surplus present fairly the position of the XYZ Company at April 30, 1939, and the results of its operations for the fiscal year, in conformity with generally accepted accounting principles applied on a basis consistent with that of the preceding year. ${ }^{44}$

\section{CONCLUSION}

The Musicas are gone, but their influence continues to be felt. This Italian immigrant family left its mark indelibly on the auditing profession. Philip, George, Robert, Arthur, Papa Antonio and Mama Assunta would probably have been surprised at the lasting effects of their rise from cheese to hair to drug fraud.

The auditing profession learned from its experiences and moved forward following McKesson \& Robbins. The way auditors were selected changed, the scope of the auditor's work expanded, the audit report more carefully detailed what was actually done, and the cost of audits increased for clients. In particular, the procedures for auditing inventories and accounts receivable were expanded.

Like many other cases that were to follow, McKesson \& Robbins emphasized the importance of the work of the auditor and the importance of auditor independence. But the process is not complete and never will be if we believe a passage marked in a book, "What Interests People and Why," found in Philip Coster's desk after his death:

'The truth...is that no practical system has ever been devised by which the complicated finances of a large institution can be thoroughly checked up so that every transaction is verified, except at prohibitive time and cost. ${ }^{, 5}$

\section{AUTHOR INFORMATION}

A. Bruce Strauch is a Professor of Business Law at The Citadel. He is a member of the N.C. and S.C. Bars, the U.S. Fourth Circuit and Fourth Circuit Court of Appeals. He is the publisher of the journal Against the Grain, and owner of the Charleston Conference.

Sheila D. Foster is Professor of Accounting and Director of Global Experiences at The Citadel. She has earned a B.S. from Radford College, a M.Ed. and a CIA from Virginia Commonwealth University, and a Ph.D. in Accounting from Virginia Tech. Dr. Foster is a Certified Public Accountant and a Certified Fraud Examiner.

\footnotetext{
${ }^{43}$ SEC, Accounting Series Releases..., p. 9.

${ }^{44}$ AIA, "Extensions of Auditing Procedure."

45 "The Ghost of Scandal Past," p. B4. This 1999 Wall Street Journal detailed a modern-day "accounting mess" in which a newly purchased McKesson \& Robbins subsidiary, McKesson HBOC, Inc. “...may have padded its fiscal 1999 revenue by booking \$42.2 million of software sales that didn’t yet exist" and was having its books re-examined by its auditors, PricewaterhouseCoopers.
} 


\section{REFERENCES}

1. American Institute of Accountants (AIA). 1941. Examination of Financial Statements by Independent Public Accountants. New York, NY.

2. American Institute of Accountants (AIA). 1941. Committee on Auditing Procedure. Extensions of Auditing Procedure. Statements on Auditing Procedures. No. 1. New York, NY.

3. American Institute of Certified Public Accountants (AICPA). 1999. Codification of Auditing Standards and Procedures. Statement on Auditing Standards. (SAS) No. 1. New York, NY:AICPA.

4. American Institute of Certified Public Accountants (AICPA). 1999. The Confirmation Process. Statement on Auditing Standards. (SAS) No. 1 (AU330). New York, NY:AICPA.

5. Coster Arms Deal is Held Doubtful. December 19, 1938. The New York Times, p. A-12.

6. Coster Reported in New Arms Deal Before Exposure. December 19, 1938. The New York Times, p. A-1 ff.

7. Flaa, John Douglas. August 1957. A Report on the McKesson \& Robbins Case. A Thesis Submittd to the Faculty of the Graduate School of the University of North Dakota, Grand Forks, North Dakota, B.S. in Commerce, University of North Dakota, 1954.

8. Keats, Charles. 1964. Magnificent Masquerade: The Strange Case of Dr. Coster and Mr. Musica. Funk \& Wagnalls Company, Inc.: New York, NY.

9. MacDonald, Elizabeth. June 30, 1999. The Ghost of Scandal Past. Wall Street Journal, pp. B-1ff.

10. No Hidden Treasures. January 2, 1939. Time, p. 30.

11. Pollack, Irving M; and Sporkin, Stanley. September 25, 2002. Roundtable on Enforcement: A Brief History of the SEC's Enforcement Program 1934-81. (Prepared by Daniel M. Hawke.) SEC Historical Society, Oral Histories Committee, September 25, 2002

12. Rappaport, Louis H. 1956. S.E.C. Accounting Practices and Procedure. New York: The Ronald Press Company. New York.

13. Sifakis, Carl. 2001. Frauds, Deceptions, and Swindles. Checkmark Books: New York, NY.

14. U.S. Securities and Exchange Commission. December 5, 1940. Release No. 19. In the Matter of McKesson \& Robbins, Inc. - Summary of findings and Conclusions." Accounting Series Releases: 1 to 63 Inclusive. Compilation of releases to 195 As in Effect August 1976. Washington: U.S. Government Printing Office, 1976. 